\title{
ANALISIS YURIDIS PERAN PEMERINTAH ACEH DALAM PELATIHAN TENAGA KERJA
}

\author{
Muhibuddin ${ }^{1}$, Nasrianti ${ }^{1}$ \\ Dosen Fakultas Hukum Universitas Malikussaleh \\ Co. Author : nasrianti@unimal.ac.id
}

\begin{abstract}
Manpower development contained in the 1945 Constitution Article 27 paragraph (2), that every citizen has the right to work and a decent living for humanity. The Aceh Government implements Article 174 paragraph (5), and Article 175 paragraph (4) of Law Number 11 Year 2006 concerning the Government of Aceh, therefore issued Qanun Number 7 of 2014 concerning Manpower and the Regulation of the Governor of Aceh Number 112 of 2016 concerning Position, Organizational Structure, Duties, Functions and Work Procedures of the Office of Manpower and Mobility of the Aceh Population. The method used in this study is a normative juridical research method that is qualitative in nature, namely research methods that refer to legal norms contained in legislation. In this study the use is referring to legal sources, namely research that refers to legal norms contained in legal instruments. Conclusion, provisions of Article 175 of Law No. 11 of 2006 concerning the Government of Aceh, that every worker has the same right to get decent work in Aceh. So the role of the Aceh Government in improving the direction of life of its people is very important in employment for the implementation of social justice in labor life.
\end{abstract}

Keywords; Role, Aceh Government, Training, Labor 


\section{A. PENDAHULUAN}

Pembangunan ketenagakerjaan telah jelas temuat di dalam UUD 1945 pasal 27 ayat (2) yang menyatakan bahwa setiap warga negara berhak atas pekerjaan dan penghidupan yang layak bagi kemanusiaan. Dari sisi ini "pekerjaan" adalah merupakan hak dasar setiap orang, karena adanya pekerjaan pada dasarnya bukan semata-mata untuk mendapatkan penghasilan, tetapi lebih dari itu harga diri dan martabat manusia juga dinilai dari aktivitas bekerja yang bersangkutan.

Undang-Undang Dasar Negara Republik Indonesia Tahun 1945 menjamin setiap warga negara Indonesia mempunyai hak dan kesempatan yang sama tanpa diskriminasi untuk memperoleh pekerjaan dan penghidupan yang layak. Bekerja merupakan hak asasi manusia yang wajib dijunjung tinggi, dihormati, dan dijamin penegakannya. Pekerja Aceh khususnya dan Pekerja Indonesia pada umumnya harus dilindungi dari perdagangan manusia, termasuk perbudakan dan kerja paksa, korban kekerasan, kesewenangwenangan, kejahatan atas harkat dan martabat manusia, serta perlakuan lain yang melanggar hak asasi manusia. Pelindungan Pekerja perlu dilakukan dalam suatu sistem yang terpadu yang melibatkan pemerintah pusat, Pemerintah Daerah, dan masyarakat. Sebagaimana disebutkan dalam UndangUndang Dasar Negara Kesatuan Republik Indonesia Tahun 1945 sebagai berikut:

Pasal 18 menyebutkan Bahwa,

1. Negara Kesatuan Republik Indonesia dibagi atas daerahdaerah provinsi dan daerah provinsi itu dibagi atas kabupaten dan Kota, yang tiap-tiap provinsi, kabupaten, dan kota itu mempunyai pemerintahan daerah, yang diatur dengan undangundang.

2. Pemerintah daerah provinsi, daerah Kabupaten, dan Kota mengatur dan mengurus sendiri urusan pemerintahan menurut asas otonomi dan tugas pembantuan.

3. Pemerintahan daerah provinsi, daerah kabupaten, dan kota memiliki Dewan Perwakilan Rakyat Daerah yang anggotaanggotanya dipilih melalui pemilihan umum.

4. Gubernur, Bupati, dan Walikota masing-masing sebagai kepala pemerintah daerah provinsi, kabupaten dan kota dipilih secara demokratis. 
5. Pemerintahan daerah menjalankan otonomi seluas-luasnya, kecuali urusan pemerintahan yang oleh undang-undang ditentukan sebagai urusan Pemerintahan Pusat.

6. Pemerintahan daerah berhak menetapkan peraturan daerah dan peraturan-peraturan lain untuk melaksanakan otonomi dan tugas pembantuan.

7. Susunan dan tata cara penyelenggaraan pemerintahan daerah diatur dalam undangundang.

Pasal 18A menyebutkan bahwa,

1. Hubungan wewenang antara pemerintah pusat dan pemerintahan daerah provinsi, kabupaten, dan kota, atau provinsi dan kabupaten dan kota, diatur dengan undang-undang dengan memperhatikan kekhususan dan keragaman daerah.

2. Hubungan keuangan, pelayanan umum, pemanfaatan sumber daya alam dan sumber daya lainnya antara pemerintah pusat dan pemerintah daerah diatur dan dilaksanakan secara adil dan selaras berdasarkan undang-undang.

\section{Selanjutnya Pasal 18B}

menyebutkan bahwa,
1. Negara mengakui dan menghormati satuan-satuan pemerintahan daerah yang bersifat khusus atau bersifat istimewa yang diatur dengan undangundang.

2. Negara mengakui dan menghormati kesatuan-kesatuan masyarakat hukum adat beserta hak-hak tradisionalnya sepanjang masih hidup dan sesuai dengan perkembangan masyarakat dan prinsip Negara Kesatuan Republik Indonesia, yang diatur dalam undang-undang.

Berdasarkan Pasal 18, 18A dan 18B Undang-Undang Dasar Negara Kesatuan Republik Indonesia Tahun 1945 maka lahirlah Undang-Undang Pemerintahan Daerah serta UndangUndang Otonomi Khusus Aceh dan Papua. Maka Pemerintahan Aceh diberikan Otonomi Khusus melahirkan kewenangan Khusus Sebagaimana yang telah diatur dalam Pasal 31 UU No. 18 Tahun 2001 tentang Otonomi Khusus Bagi Aceh sebelum keluar UU Pemerintahan Aceh menyebutkan, bahwa ketentuan pelaksanaan undangundang ini yang menyangkut kewenangan pemerintah ditetapkan dengan peraturan pemerintah, sedangkan yang menyangkut kewenangan pemerintah Provinsi Nanggroe Aceh Darussalam ditetapkan Dengan Qanun Provinsi Nanggroe Aceh Darussalam. 
Pasal 1 ayat (8) UU Otonomi Khusus disebutkan, pengertian Qanun Provinsi Nanggroe Aceh Darussalam adalah Peraturan Daerah sebagai pelaksanaan undang-undang di wilayah Provinsi Nanggroe Aceh Darussalam dalam rangka penyelenggaraan otonomi khusus. Berdasarkan ketentuan tersebut Pemerintahan Aceh diberikan kekuasaan dan wewenang yang lebih dari daerah lain di Indonesia untuk membuat peraturan daerah yang disebut dengan Qanun, sebagai peraturan daerah untuk mengurus rumah tangganya sendiri. denga diberikan kebebasan untuk membuat Qanun sebagai pelaksanaan dari Undang-Undang Otonomi Khusus, karena Qanun merupakan setingkat dengan Peraturan Daerah yang khusus dibuat sesuai dengan kewenangan yang diberikan kepada pemerintahan daerah. Pemerintahan Daerah adalah sebagai satuan Pemerintahan teritorial tingkat lebih rendah yang berhak mengatur dan mengurus sebagian urusan pemerintahan sebagai urusan rumah tangganya sendiri. Urusan rumah tangga daerah bersumber pada otonomi dan tugas pembantuan (medebewind). Sistem otonomi yang dijalankan sekarang adalah otonomi riil atau nyata, baik otonomi luas maupun otonomi khusus.
Berdasarkan UU OTSUS ini Qanun Provinsi Nanggroe Aceh Darussalam adalah peraturan daerah Provinsi Nanggroe Aceh Darussalam, yang dapat menyampingkan peraturan perundang-undangan lain, dan Mahkamah Agung berwenang melakukan uji materil terhadap Qanun. Supardan Modeong menyebutkan, bila kita melihat dari sudut prosedur pembuatan peraturan perundangundangan antara Peraturan Daerah (Perda) dengan Qanun adalah sama. Yaitu peraturan yang dibuat oleh Dewan Perwakilan Daerah bersama-sama dengan Gubernur untuk mengatur penyelenggaraan pemerintahan daerah dalam rangka otonomi daerah. Namun ditinjau dari sudut keuasaan mengatur Qanun berbeda dengan mengatur Perda. karena disebabkan Qanun tidak tunduk pada Peraturan Pemerintah (PP) dan Keputusan Presiden (Keppres), sedangkan Peraturan Daerah tunduk kepada dua hal tersebut. Oleh karena itu sebagaiamana peraturan perundangundangan yang lain mempunyai kekuatan mengikat dan dapat dipaksakan, maka demikian sama juga halnya dengan Qanun. Pemerintahan Aceh untuk melaksanakan ketentuan Pasal 174 ayat (5), dan Pasal 175 ayat (4) Undang-Undang Nomor 11 Tahun 2006 tentang Pemerintahan Aceh, untuk 
melaksanakan ketentuan pasal tersebut sesuai amanat Undang-undang Pemerintahan Aceh, maka Pemerintahan Aceh mengerluarkan Qanun Nomor 7 Tahun 2014 tentang Ketenagakerjaan, serta mengeluarkan Peraturan Gubernur Aceh Nomor 112 Tahun 2016 tentang Kedudukan, Susunan Organisasi, Tugas, Fungsi dan Tata Kerja Dinas Tenaga kerja dan mobilitas Penduduk Aceh. Berdasarkan latarbelakang masalah tersebut diatas, maka penulis ingin mengkaji lebih lanjut dengan Judul "Analisis Yuridis Peran Pemerintahan Aceh Dalam Pelatihan Tenaga Kerja Aceh".

\section{B. PERMASALAHAN}

Penelitian ini ditujukan untuk menjawab pertanyaan tentang Peran Pemerintah Aceh Dalam Pelatihan Tenaga Kerja menurut Peraturan Perundang-undangan. Sifat Penelitian yang digunakan adalah penelitian yuridis normatif, yaitu penelitian yang difokuskan untuk mengkaji penerapan kaidah atau norma-norma dalam hukum positif. Penelitian ini bersifat deskriptif analitis. Tujuan penelitian deskriptif adalah menggambarkan secara tepat, sifat individu, suatu gejala, keadaan atau kelompok tertentu. (Kontjaraningrat, 1997: 42) Deskriptif analitis berarti bahwa penelitian ini menggambarkan dan menganalisis suatu peraturan hukum dalam konteks teori-teori dan normanorma hukum tentang fakta dan kondisi atau gejala yang menjadi objek penelitian. Setelah itu diadakan suatu telaah secara kritis dalam arti meberikan penjelasan-penjelasan atas fakta atau gejala tersebut, baik dalam kerangka sistematisasi maupun sinkronisasi dengan berdasarkan pada aspek yuridis, dengan demikian akan menjawab permasalahan yang menjadi objek penelitian.

\section{PEMBAHASAN}

1. Analisis Yuridisn Peran

Pemerintahan Aceh Dalam

Pelatihan Tenaga Kerja Aceh Menurut Peraturan Perundangundangan

Pembangunan ketenagakerjaan sebagai bagian integral dari pembangunan Aceh, dilaksanakan dalam rangka untuk meningkatkan harkat, martabat, dan harga diri tenaga kerja serta mewujudkan masyarakat sejahtera, adil, makmur, dan merata, baik material maupun spiritual. Pembangunan ketenagakerjaan harus diatur sedemikian rupa sehingga terpenuhi hak-hak dan perlindungan yang mendasar bagi tenaga kerja dan pekerja/buruh serta pada saat yang bersamaan dapat mewujudkan kondisi yang kondusif bagi pengembangan dunia usaha. 
Pembangunan ketenagakerjaan mempunyai banyak dimensi dan keterkaitan tidak hanya dengan kepentingan tenaga kerja sebelum, selama dan sesudah masa kerja tetapi juga keterkaitan dengan kepentingan pengusaha, pemerintah dan masyarakat. Untuk itu, diperlukan pengaturan ketenagakerjaan yang antara lain mencakup pengembangan sumber daya manusia, peningkatan produktivitas dan daya saing tenaga kerja dan pembinaan hubungan industrial. Dalam hal ini setiap tenaga kerja berhak mendapat pelindungan dan kesejahteraan berdasarkan peraturan perundangundangan.

Berdasarkan ketentuan dalam Pasal 175 Undang-Undang Nomor 11 Tahun 2006 tentang Pemerintahan Aceh, setiap tenaga kerja mempunyai hak yang sama untuk mendapat pekerjaan yang layak di Aceh. Dalam hal ini Pemerintah Aceh dan Pemerintah Kabupaten/Kota memberikan kesempatan dan pelindungan kerja bagi tenaga kerja di Aceh dan dapat bekerja sama dengan pemerintah provinsi dan kabupaten/kota asal tenaga kerja yang bersangkutan. Selanjutnya, semua tenaga kerja di Aceh harus terdaftar pada instansi yang bertanggung jawab di bidang ketenagakerjaan masing-masing Kabupaten/Kota. Karena hak dan kewajiban Pemeritahan Daerah telah diberikan Otonomi Daerah yang mengatur dan memberikan wewenang dan kewajiban yang lebih menekan pada daerah otonom untuk mengatur dan mengurus sendiri urusan pemerintahan dan kepentingan masyarakat setempat sesuai dengan peraturan perundangundangan dengan tujuan meningkatkan kesejahteraan masyarakat, pelayanan umum dan daya sain daerah.

Sebelum diamandemen Pasal 18 menyatakan, bahwa pembagian daerah Indonesia atas daerah besar dan kecil, dengan bentuk susunan pemerintahannya ditetapkan dengan undang-undang, dengan memandang dan mengingat dasar permusyawaratan dalam system pemerintahan negara, dan hak-hak asal-usul dalam daerah-daerah yang bersifat istimewa. Maka sistem demokrasi di Indonesia sangat diutamakan dalam penyelenggaraan pemerintahan daerah.

Sebab demokrasi dipraktekan secara langsung (direct democracy), artinya hak rakyat untuk membuat keputusan-keputusan politik dijalankan secara langsung oleh seluruh warga Negara yang bertidak berdasarkan prosedur mayoritas. Pada hakikatnya demokrasi adalah pelembagaan dari kebebasan. Penyelenggaraan pemerintan daerah di berikan kebebesan untuk 
menyelenggarakan pemerintahan secara mandiri dan sesuai dengan otonomi yang diberikan oleh Undang-Undang.

Sedangkan dalam pemerintahan daerah Indonesia, demokrasi mengandung tiga arti yaitu pertama, demokrasi dikaitkan dengan sistem pemerintahan, dalam arti bagaimana caranya rakyat diikut sertakan dalam penyelenggaraan pemerintahan; kedua, demokrasi sebagai asas yang dipengaruhi oleh perjalanan histories bangsa Indonesia; ketiga, demokrasi sebagai solusi tentative untuk menyelesaikan beberapa persoalan yang dihadapi dalam rangka penyelenggaraan negara sehingga lahir istilah musyawarah mufakat. Dalam kontek itulah sejarah penyelenggaraan Pemerintahan Republik Indonesia menunjukkan, bahwa otonomi daerah merupakan salah satu sendi penting penyelenggaraan pemerintahan Negara.

Otonomi daerah diadakan bukan sekedar menjamin efisiensi dan efektifitas penyelenggaraan pemerintahan bukan pula sekedar menampung kenyataan Negara yang luas, penduduk banyak dan beribu-ribu pulau. Akan tetapi otonomi daerah merupakan dasar memperluas pelaksanaan demokrasi dan instrument dalam rangka mewujudkan kemakmuran dan kesejahteraan rakyat bahkan tidak kalah pentingnya bahwa otonomi daerah merupakan salah satu sendi ketatanegaraan Republik Indonesia.

Daerah otonomi yang bebas dan mandiri mengatur dan mengurus rumah tangganya sendiri merasa diberi tempat yang layak dalam kehidupan berbangsa dan bernegara sehingga tidak ada alasan untuk keluar dari Negara Kesatuan Republik Indonesia. Sebelum reformasi Penyelenggaraan pemerintahan daerah tidak dijalankan sebagaimana mestinya, daerah tidak diberdayakan untuk mandiri melainkan di buat serba tergantung dan harus mematuhi kehendak pusat. Urusan rumah tangga daerah terbatas dan serba diawasi. Keuangan daerah serba tergantung pada kebaikan hati pemerintahan pusat. Hal semacam ini menimbulkan kecewaan luar biasa pada daerah.

Untuk meningkatkan kesejahteraan masyarakatnya, Pemerintahan Aceh membuat suatu kebijakan dengangan mengeluarkan suatu peraturan yang mengatur perlindungan terhadap tenaga kerja Aceh sesuai amanat Undang-Undang No. 11 Tahun 2006 tentang Pemerintahan Aceh yaitu sebagai berikut:

Pasal 174 menyebutkan;

1. Pemerintah Aceh dan pemerintah kabupaten/kota berwenang 
mengeluarkan izin usaha jasa pengerahan tenaga kerja ke luar negeri berdasarkan peraturan perundangundangan.

2. Setiap tenaga kerja berhak mendapat pelindungan dan kesejahteraan berdasarkan peraturan perundang-undangan.

3. Setiap badan usaha jasa pengerahan tenaga kerja ke luar negeri berkewajiban mengadakan pendidikan dan pelatihan keterampilan yang sesuai dengan kebutuhan tempat bekerja.

4. Pemerintah, Pemerintah Aceh dan pemerintah kabupaten/kota memberikan pelindungan bagi tenaga kerja yang berasal dari Aceh dan kabupaten/kota yang bekerja di luar negeri bekerja sama dengan pemerintah negara tujuan.

5. Ketentuan lebih lanjut mengenai pengerahan tenaga kerja ke luar negeri dan tata cara pelindungan diatur dalam qanun berdasarkan peraturan perundang-undangan.

Menindaklanjuti amanat Pasal 174 tersebut diatas, maka Pemerintahan Aceh mengeluarkan Qanun No. 7 Tahun 2014 tentang ketenagakerjaan, dalam penjelasannya menyebutkan Pembangunan ketenagakerjaan sebagai bagian integral dari pembangunan Aceh, dilaksanakan dalam rangka untuk meningkatkan harkat, martabat, dan harga diri tenaga kerja serta mewujudkan masyarakat sejahtera, adil, makmur, dan merata, baik material maupun spiritual. Pembangunan ketenagakerjaan harus diatur sedemikian rupa sehingga terpenuhi hak-hak dan perlindungan yang mendasar bagi tenaga kerja dan pekerja/buruh serta pada saat yang bersamaan dapat mewujudkan kondisi yang kondusif bagi pengembangan dunia usaha Pembangunan ketenagakerjaan mempunyai banyak dimensi dan keterkaitan tidak hanya dengan kepentingan tenaga kerja sebelum, selama dan sesudah masa kerja tetapi juga keterkaitan dengan kepentingan pengusaha, pemerintah dan masyarakat. Untuk itu, diperlukan pengaturan ketenagakerjaan yang antara lain mencakup pengembangan sumber daya manusia, peningkatan produktivitas dan daya saing tenaga kerja dan pembinaan hubungan industrial. Berdasarkan ketentuan dalam Pasal 174 UndangUndang Nomor 11 Tahun 2006 tentang Pemerintahan Aceh.

Pemerintah Aceh dan Pemerintah Kabupaten/Kota berwenang mengeluarkan izin usaha jasa pengerahan tenaga kerja ke luar negeri berdasarkan peraturan perundangundangan. Dalam hal ini setiap tenaga kerja berhak mendapat pelindungan dan 
kesejahteraan berdasarkan peraturan perundang-undangan. Setiap badan usaha jasa pengerahan tenaga kerja ke luar negeri berkewajiban mengadakan pendidikan dan pelatihan keterampilan yang sesuai dengan kebutuhan tempat bekerja. Oleh karena itu, Pemerintah, Pemerintah Aceh dan Pemerintah Kabupaten/Kota harus memberikan perlindungan bagi tenaga kerja yang berasal dari Aceh dan Kabupaten/Kota yang bekerja di luar negeri bekerja sama dengan pemerintah negara tujuan.

$$
\text { Pasal } 1 \text { Qanun No. } 7 \text { Tahun }
$$

2014 tentang ketenagakerjaan menyebutkan;Pemerintah Pusat yang selanjutnya disebut Pemerintah adalah Presiden Republik Indonesia yang memegang kekuasaan pemerintahan Negara Republik Indonesia sebagaimana dimaksud dalam Undang-Undang Dasar Negara Republik Indonesia Tahun 1945. Aceh adalah daerah provinsi yang merupakan kesatuan masyarakat hukum yang bersifat istimewa dan diberi kewenangan khusus untuk mengatur dan mengurus sendiri urusan pemerintahan dan kepentingan masyarakat setempat sesuai dengan Peraturan Perundangundangan dalam sistem dan prinsip Negara Kesatuan Republik Indonesia berdasarkan Undang-Undang Dasar Negara Republik Indonesia Tahun 1945 yang dipimpin oleh seorang Gubernur.
3. Kabupaten/Kota adalah bagian dari daerah provinsi sebagai suatu kesatuan masyarakat hukum yang diberi kewenangan khusus untuk mengatur dan mengurus sendiri urusan pemerintahan dan kepentingan masyarakat setempat sesuai dengan peraturan perundangundangan dalam sistem dan prinsip Negara Kesatuan Republik Indonesia berdasarkan Undang-Undang Dasar Negara Republik Indonesia Tahun 1945, yang dipimpin oleh seorang Bupati/Walikota. 4. Pemerintah Aceh adalah unsur penyelenggara Pemerintahan Aceh yang terdiri dari Gubernur dan Perangkat Aceh. Gubernur adalah Kepala Pemerintah Aceh yang dipilih melalui suatu proses demokratis yang dilakukan berdasarkan asas langsung, umum, bebas, rahasia, jujur, dan adil.

1.Pemerintah Kabupaten/Kota adalah unsur penyelenggara Pemerintahan Kabupaten/Kota yang terdiri atas Bupati/Walikota dan Perangkat Kabupaten/Kota.

2.Bupati/Walikota adalah Kepala Pemerintah Kabupaten/Kota yang dipilih melalui suatu proses demokratis yang dilakukan berdasarkan asas langsung, umum, bebas, rahasia, jujur, dan adil. 
3.Satuan Perangkat Kerja Aceh selanjutnya disebut SKPA adalah Satuan Perangkat Kerja Daerah di lingkungan Pemerintah Aceh yang mempunyai tugas pokok, fungsi dan kewenangan di bidang ketenagakerjaan.

\section{Satuan Perangkat Kerja} Kabupaten/Kota selanjutnya disebut SKPK adalah Satuan Perangkat Kerja Daerah di lingkungan Pemerintah Kabupaten/Kota yang mempunyai tugas pokok, fungsi dan kewenangan di bidang ketenagakerjaan.

5.Ketenagakerjaan adalah segala hal yang berhubungan dengan tenaga kerja pada waktu sebelum, selama dan sesudah masa kerja.

6.Tenaga Kerja adalah setiap orang yang mampu melakukan pekerjaan guna menghasilkan barang dan/atau jasa baik untuk memenuhi kebutuhan sendiri maupun untuk masyarakat.

7.Tenaga Kerja Aceh adalah Tenaga Kerja yang bertempat tinggal secara menetap di Aceh tanpa membedakan suku, ras, agama, dan keturunan.

\section{Pekerja/Buruh adalah setiap} orang yang bekerja dengan menerima upah atau imbalan dalam bentuk lain.
9.Pemberi Kerja adalah orang perseorangan, pengusaha, badan hukum, atau badan-badan lainnya yang memperkerjakan tenaga kerja dengan membayar upah atau imbalan dalam bentuk lain.

10.Pengguna Jasa adalah Instansi Pemerintah atau Badan Usaha berbentuk badan hukum, perusahaan dan perorangan didalam atau di luar negeri yang bertanggungjawab mempekerjakan tenaga kerja.

11.Pengusaha adalah:

a. orang perseorangan, persekutuan, atau badan hukum yang menjalankan suatu perusahaan milik sendiri;

b. orang perseorangan, persekutuan, atau badan hukum yang secara berdiri sendiri menjalankan perusahaan bukan miliknya;

c. orang perseorangan, persekutuan, atau badan hukum yang berada di Indonesia mewakili perusahaan sebagaimana dimaksud dalam huruf a dan huruf $b$ yang berkedudukan di luar wilayah Indonesia.

17.

Perusahaan adalah: setiap bentuk usaha yang berbadan hukum atau tidak, milik orang perseorangan, milik persekutuan, atau milik badan hukum, baik milik swasta 
maupun milik negara yang memperkerjakan Pekerja/Buruh dengan membayar upah atau imbalan.

a. usaha-usaha sosial dan usaha-usaha lain yang mempunyai pengurus dan memperkerjakan orang lain dengan membayar upah atau imbalan dalam bentuk lain.

\section{Perencanaan Tenaga Kerja} adalah proses penyusunan rencana ketenagakerjaan secara sistimatis yang dijadikan dasar dan acuan dalam penyusunan kebijakan, strategi dan pelaksanaan program pembangunan ketenagakerjaan yang berkesinambungan.

19. Informasi Ketenagakerjaan adalah gabungan, rangkaian dan analisis data yang berbentuk angka yang telah diolah, naskah dan dokumen yang mempunyai arti, nilai dan makna tertentu mengenai ketenagakerjaan.

20. Bursa Kerja adalah tempat penyelenggaraan pelayanan antar kerja.

21. Pelatihan Kerja adalah keseluruhan kegiatan untuk memberi, memperoleh, meningkatkan, serta mengembangkan kompetensi kerja, produktivitas, disiplin, sikap, dan etos kerja pada tingkat keterampilan dan keahlian tertentu sesuai dengan jenjang dan kualifikasi jabatan atau pekerjaan.

22. Lembaga Pelatihan Kerja adalah lembaga yang menyelenggarakan pelatihan kerja bagi tenaga kerja dan memenuhi persyaratan yang ditetapkan.

23. Sertifikat Pelatihan adalah tanda bukti penetapan dan pengakuan atas jenis dan tingkat keterampilan yang dimiliki/dikuasai oleh seseorang sesuai dengan standar program pelatihan yang ditetapkan.

24. Pemagangan adalah bagian dari sistem pelatihan kerja yang diselenggarakan secara terpadu antara pelatihan di lembaga pelatihan dengan bekerja secara langsung di bawah bimbingan dan pengawasan instruktur atau Pekerja/Buruh yang lebih berpengalaman, dalam proses produksi barang dan/atau jasa di perusahaan, dalam rangka menguasai ketrampilan atau keahlian tertentu.

25. Pelayanan Penempatan Tenaga Kerja adalah kegiatan untuk mempertemukan tenaga kerja dengan pemberi kerja, sehingga tenaga kerja dapat memperoleh pekerjaan yang sesuai dengan bakat, minat dan kemampuannya, dan pemberi kerja dapat memperoleh tenaga kerja yang sesuai dengan dengan kebutuhannya. 
26. Keselamatan dan

Kesehatan Kerja yang selanjutnya disingkat K3 adalah upaya keselamatan dan kesehatan kerja dimaksudkan untuk memberikan jaminan keselamatan dan meningkatkan derajat kesehatan para Pekerja/Buruh dengan cara pencegahan kecelakaan dan penyakit akibat kerja, pengendalian bahaya di tempat kerja, promosi kesehatan, pengobatan, dan rehabilitasi.

Untuk melaksanakan Qanun No.

7 Tahun 2014 tentang ketenagakerjaan, maka Pemerintahan Aceh mengeluarkan Peraturan Gubernur Aceh Nomor 112 Tahun 2016 tentang Kedudukan, Susunan Organisasi, Tugas, Fungsi dan Tata Kerja Dinas Tenaga kerja dan mobilitas Penduduk Aceh.

\section{Kewenangan Pemerintah Aceh} dalam Pelatihan Tenaga Kerja

Peran Pemerintahan Daerah dalam meningkatkan tarah hidup masyarakatnya sangat penting dalam lapangan kerja karena menurut Iman Soepomo memiliki tujuan pokok pelaksanaan keadilan sosial dalam bidang perburuhan dan pelaksanaannya diselenggarakan dengan jalan melindungi pekerja terhadap kekuasaan yang tidak terbatas dari pihak majikan. Begitu pula menurut Senjun $H$. Manulang, yaitu untuk mencapai atau melaksanakan keadilan sosial dalam bidang ketenagakerjaan dan untuk melindungi tenaga kerja terhadap kekuasaan yang tidak terbatas dari pengusaha, misalnya dengan membuat perjanjian atau menciptakan peraturanperaturan yang bersifat memaksa agar pengusaha tidak bertindak sewenangwenang terhadap tenaga kerja. Dalam rangka mewujudkan tujuan pokok hukum perburuhan tersebut, maka perlindungannya tidak hanya ditingkat nasional suatu negara, tetapi juga bersifat internasional (sedunia) (Dede, 2019).

Perlindungan Tenaga Kerja
sangat menjadi perhatian dunia
internasional dengan mengeluaran
Konvensi tentang perlindungan terhadap kesejahteraan Tenaga Kerja dan Negara telah mengakui pentingnya perlindungan dan terjaminnya kesejahteraan para pekrja dengan merativikasi beberapa Konvensi ILO oleh pemerintah Indonesia beserta peraturan perundangundangan nasional yang meratifikasinya adalah sebagai berikut :

\section{Konvensi ILO Nomor} 81 tentang Pengawasan Ketenagakerjaan dalam Industri dan Perdagangan (diratifikasi dengan Undang-udang No. 21 Tahun 2003)

\section{Konvensi ILO Nomor}

87 tentang Kebebasan Berserikat dan 
Perlindungan Hak Untuk Berorganisasi (diratifikasi dengan Keputusan Presiden No. 83 Tahun 1998).

3. Konvensi ILO Nomor 98 tentang Hak Berorganisasi dan Berunding Bersama (diratifikasi dengan Undang-undang No. 18 Tahun 1956).

4. Konvensi ILO Nomor 105 tentang Penghapusan Kerja Paksa (diratifikasi dengan Undang-undang No. 19 Tahun 1999).

$\begin{array}{cccc} & 5 . & \text { Konvensi ILO Nomor } \\ 111 \text { tentang } & \text { Diskriminasi } & \text { Dalam }\end{array}$
Pekerjaan dan Jabatan (diratifikasi dengan Undang-undang No. 21 Tahun 1999).

6. Konvensi ILO Nomor 138 tentang Usia Minimum Untuk dibolehkan Bekerja (diratifikasi dengan Undang-undang No. 20 Tahun 1999).

7. Konvensi ILO No.182 tentang Pelarangan dan Tindakan Segera Penghapusan Bentuk-bentuk Pekerjaan Terburuk untuk Anak (diratifikasi dengan Undang-undang No. 1 Tahun 2000).

8. Konvensi ILO No.100 tentang Kesamaan Pengupahan (diratifikasi dengan Undang-undang No. 80/1957).

9. Konvensi ILO No.144 tentang Konsultasi Tripartit Untuk Meningkatkan Pelaksanaan Standar Perburuhan Internasional (diratifikasi dengan Keputusan Presiden No. 26 Tahun 1990).

10. Konvensi ILO Nomor 106 tentang Istirahat Mingguan dalam Perdagangan dan Kantor-kantor (diratifikasi dengan Undang-undang No. 3 Tahun 1961).

11. Konvensi ILO No. 29 tentang Kerja Paksa atau Wajib Kerja (diratifikasi dengan Stbl. 261, 1933).

12. Konvensi ILO No.19 tentang Perlakuan Yang Sama Bagi Pekerja Nasional dan Asing dalam Hal Tunjangan Kecelakaan Kerja (diratifikasi dengan Stbl. 53, 1929).

13. Konvensi ILO No. 27 tentang Pemberian Tanda Berat pada Pengepakan Barang-barang Besar yang Diangkut dengan Kapal (diratifikasi dengan Stbl.117, 1933).

14. Konvensi ILO Nomor 45 tentang Kerja Wanita pada Segala Macam Tambang (diratifikasi dengan Stbl. 219, 1937).

15. Konvensi ILO Nomor 120 tentang Hygiene dalam Perniagaan dan Kantor-kantor (diratifikasi dengan Undang-undang No. 3 Tahun 1969).

16. Konvensi ILO Nomor 68 tentang Sertifikasi Bagi Juru Masak di Kapal (diratifikasi dengan Keputusan Presiden No. 4 Tahun 1992).

17. Konvensi ILO Nomor 88 tentang Lembaga Pelayanan 
Penempatan Tenaga Kerja (diratifikasi dengan Keputusan Presiden No. 36 Tahun 2002).

18. Konvensi ILO Nomor 185 tentang Perubahan Dokumen Identitas Pelaut (diratifikasi dengan Undang-undang No. 1 Tahun 2008).

Berdasarkan konvensi ILO dan Peraturan Perundang-undangan yang telah diberlakukan di Indonesia dan Pemerintahan yang telah diberikan Otonomi Khusus dan Daerah Istimewa melaluai Undang-Undang Nomor 11 Tahun 2006 tentang Pemerintahan Aceh serta Undang-Undang Nomor 44 Tahun 1999 tentang Derah Keistimewaan Aceh, dalan penjelasan Undang-Undang Pemerintahan Aceh menyebutkan Undang-Undang ini mengatur dengan tegas bahwa Pemerintahan Aceh merupakan bagian yang tidak terpisahkan dari Negara Kesatuan Republik Indonesia dan tatanan otonomi seluasluasnya yang diterapkan di Aceh berdasarkan Undang-Undang ini merupakan subsistem dalam sistem pemerintahan secara nasional. Dengan demikian, otonomi seluas-luasnya pada dasarnya bukanlah sekadar hak, tetapi lebih dari itu yaitu merupakan kewajiban konstitusional untuk dimanfaatkan sebesar-besarnya bagi kesejahteraan di Aceh.
Pengaturan dalam qanun yang banyak diamanatkan dalam UndangUndang ini merupakan wujud konkret bagi terselenggaranya kewajiban konstitusional tersebut dalam pelaksanaan Pemerintahan Aceh dan kabupaten/kota, dan merupakan acuan yang bermartabat untuk mengelola urusan pemerintahan secara mandiri sebagai bagian dari wilayah kedaulatan Negara Kesatuan Republik Indonesia. Berdasarkan kewenangan yang di amanatkan Undang-Undang Pemerintahan Aceh maka di keluarkan Qanun No. 7 Tahun 2014 tentang ketenagakerjaan, Pasal 174 UndangUndang Nomor 11 Tahun 2006 tentang Pemerintahan Aceh, Pemerintah Aceh dan Pemerintah Kabupaten/Kota berwenang mengeluarkan izin usaha jasa pengerahan tenaga kerja ke luar negeri berdasarkan peraturan perundangundangan. Dalam hal ini setiap tenaga kerja berhak mendapat pelindungan dan kesejahteraan berdasarkan peraturan perundang-undangan. Setiap badan usaha jasa pengerahan tenaga kerja ke luar negeri berkewajiban mengadakan pendidikan dan pelatihan keterampilan yang sesuai dengan kebutuhan tempat bekerja. Oleh karena itu, Pemerintah, Pemerintah Aceh dan Pemerintah Kabupaten/Kota harus memberikan perlindungan bagi tenaga kerja yang 
berasal dari Aceh dan Kabupaten/Kota yang bekerja di luar negeri bekerja sama dengan pemerintah negara tujuan.

Untuk mendukung meningkatkan ketrampilan tenaga kerja yang sesuai dengan kebutuhan tempat kerja maka Pemerintahan Aceh sangat berperan dalam memberikan pendidikan dan pelatihan untuk tenaga kerja yang siap pakai di dalam lapangan kerja dengan mengeluarkan Peraturan Gubernur Aceh Nomor 112 Tahun 2016 tentang Kedudukan, Susunan Organisasi, Tugas, Fungsi dan Tata Kerja Dinas Tenaga kerja dan mobilitas Penduduk Aceh. Pasal 1 menyebutkan,

1. Aceh adalah daerah provinsi yang merupakan kesatuan masyarakat hukum yang bersifat istimewa dan diberi kewenangan khusus untuk mengatur dan mengurus sendiri urusan pemerintahan dan kepentingan masyarakat setempat sesuai dengan Peraturan Perundang-undangan dalam sistem dan prinsip Negara Kesatuan Republik Indonesia berdasarkan Undang-Undang Dasar Negara Republik Indonesia Tahun 1945 yang dipimpin oleh seorang Gubernur.

2. Kabupaten/Kota adalah bagian dari daerah provinsi sebagai suatu kesatuan masyarakat hukum yang diberi kewenangan khusus untuk mengatur dan mengurus sendiri urusan pemerintahan dan kepentingan masyarakat setempat sesuai dengan peraturan perundang-undangan dalam sistem dan prinsip Negara Kesatuan Republik Indonesia berdasarkan Undang-Undang Dasar Negara Republik Indonesia Tahun 1945, yang dipimpin oleh seorang Bupati/Walikota.

3. Pemerintah Aceh adalah unsur penyelenggara Pemerintahan Aceh yang terdiri dari Gubernur dan Perangkat Aceh.

4. Gubernur adalah Kepala Pemerintah Aceh yang dipilih melalui suatu proses demokratis yang dilakukan berdasarkan asas langsung, umum, bebas, rahasia, jujur, dan adil.

\section{Satuan Perangkat Kerja} Aceh selanjutnya disebut SKPA adalah Satuan Perangkat Kerja Daerah di lingkungan Pemerintah Aceh yang mempunyai tugas pokok, fungsi dan kewenangan di bidang ketenagakerjaan.

6. Ketenagakerjaan adalah segala hal yang berhubungan dengan tenaga kerja pada waktu sebelum, selama dan sesudah masa kerja.

7. Tenaga Kerja adalah setiap orang yang mampu melakukan pekerjaan guna menghasilkan barang dan/atau jasa baik untuk memenuhi 
kebutuhan sendiri maupun untuk masyarakat.

8. Tenaga Kerja Aceh adalah Tenaga Kerja yang bertempat tinggal secara menetap di Aceh tanpa membedakan suku, ras, agama, dan keturunan.

9. Pekerja/Buruh adalah setiap orang yang bekerja dengan menerima upah atau imbalan dalam bentuk lain.

10. Pemberi Kerja adalah orang perseorangan, pengusaha, badan hukum, atau badan-badan lainnya yang memperkerjakan tenaga kerja dengan membayar upah atau imbalan dalam bentuk lain.

11. Pengguna Jasa adalah Instansi Pemerintah atau Badan Usaha berbentuk badan hukum, perusahaan dan perorangan didalam atau di luar negeri yang bertanggungjawab mempekerjakan tenaga kerja.

12. Pengusaha adalah:

a. orang perseorangan, persekutuan, atau badan hukum yang menjalankan suatu perusahaan milik sendiri;

b. orang perseorangan, persekutuan, atau badan hukum yang secara berdiri sendiri menjalankan perusahaan bukan miliknya;

c. orang perseorangan, persekutuan, atau badan hukum yang berada di Indonesia mewakili perusahaan sebagaimana dimaksud dalam huruf a dan huruf $b$ yang berkedudukan di luar wilayah Indonesia.

13. Perusahaan adalah:

a. setiap bentuk usaha yang berbadan hukum atau tidak, milik orang perseorangan, milik persekutuan, atau milik badan hukum, baik milik swasta maupun milik negara yang memperkerjakan Pekerja/Buruh dengan membayar upah atau imbalan dalam bentuk lain;

b. usaha-usaha sosial dan usaha-usaha lain yang mempunyai pengurus dan memperkerjakan orang lain dengan membayar upah atau imbalan dalam bentuk lain.

\section{Perencanaan Tenaga} Kerja adalah proses penyusunan rencana ketenagakerjaan secara sistimatis yang dijadikan dasar dan acuan dalam penyusunan kebijakan, strategi dan pelaksanaan program pembangunan ketenagakerjaan yang berkesinambungan.

15. Pelatihan Kerja adalah keseluruhan kegiatan untuk memberi, 
memperoleh, meningkatkan, serta

sesuai dengan bakat, minat dan mengembangkan kompetensi kerja, kemampuannya, dan pemberi kerja produktivitas, disiplin, sikap, dan etos kerja pada tingkat keterampilan dan keahlian tertentu sesuai dengan jenjang dan kualifikasi jabatan atau pekerjaan.

\section{Lembaga Pelatihan} Kerja adalah lembaga yang menyelenggarakan pelatihan kerja bagi tenaga kerja dan memenuhi persyaratan yang ditetapkan.

17. Sertifikat Pelatihan adalah tanda bukti penetapan dan pengakuan atas jenis dan tingkat keterampilan yang dimiliki/dikuasai oleh seseorang sesuai dengan standar program pelatihan yang ditetapkan.

18. Pemagangan adalah bagian dari sistem pelatihan kerja yang diselenggarakan secara terpadu antara pelatihan di lembaga pelatihan dengan bekerja secara langsung di bawah bimbingan dan pengawasan instruktur atau Pekerja/Buruh yang lebih berpengalaman, dalam proses produksi barang dan/atau jasa di perusahaan, dalam rangka menguasai ketrampilan atau keahlian tertentu.

19. Pelayanan Penempatan Tenaga Kerja adalah kegiatan untuk mempertemukan tenaga kerja dengan pemberi kerja, sehingga tenaga kerja dapat memperoleh pekerjaan yang dapat memperoleh tenaga kerja yang sesuai dengan dengan kebutuhannya.

20. Keselamatan dan Kesehatan Kerja yang selanjutnya disingkat K3 adalah upaya keselamatan dan kesehatan kerja dimaksudkan untuk memberikan jaminan keselamatan dan meningkatkan derajat kesehatan para Pekerja/Buruh dengan cara pencegahan kecelakaan dan penyakit akibat kerja, pengendalian bahaya di tempat kerja, promosi kesehatan, pengobatan, dan rehabilitasi.

21. Perjanjian Kerja yang selanjutnya disingkat PK adalah perjanjian antara Pekerja/Buruh dengan pengusaha atau pemberi kerja yang memuat syarat-syarat kerja, hak, dan kewajiban para pihak.

22. Hubungan Kerja adalah hubungan antara pengusaha dengan Pekerja/Buruh berdasarkan PK, yang mempunyai unsur pekerja, upah, dan pemerintah.

23. Hubungan Industrial adalah suatu sistem hubungan yang terbentuk antara para pelaku dalam proses produksi barang dan/atau jasa yang terdiri dari unsur pengusaha, pekerja/buruh, dan Pemerintah yang didasarkan pada nilai-nilai Pancasila dan 
Undang-Undang Dasar Negara Republik Indonesia Tahun 1945.

\section{Serikat Pekerja/Serikat} Buruh yang selanjutnya disingkat SP/SB adalah organisasi yang dibentuk dari, oleh, dan untuk Pekerja/Buruh baik di perusahaan maupun di luar perusahaan, yang bersifat bebas, terbuka, mandiri, demokrasi, dan bertanggung jawab guna memperjuangkan, membela serta melindungi hak dan kepentingan Pekerja/Buruh serta meningkatkan kesejahteraan Pekerja/Buruh dan keluarganya.

\section{Lembaga Kerja Sama} Bipartit yang selanjutnya disebut LKS Bipartit adalah forum komunikasi dan konsultasi mengenai hal-hal yang berkaitan dengan hubungan industrial di satu perusahaan yang anggotanya terdiri dari pengusaha dan serikat Pekerja/Buruh yang sudah tercatat di instansi yang bertanggung jawab di bidang ketenagakerjaan atau unsur pekerja/buruh.

26. Lembaga Kerja Sama Tripartit yang selanjutnya disebut LKS Tripartit adalah forum komunikasi, konsultasi dan musyawarah tentang masalah ketenagakerjaan yang anggotanya terdiri dari unsur organisasi pengusaha, serikat pekerja/serikat buruh, dan pemerintah.
27. Peraturan Perusahaan yang selanjutnya disingkat PP adalah peraturan yang dibuat secara tertulis oleh pengusaha yang memuat syaratsyarat kerja dan tata tertib perusahaan.

28. Perjanjian Kerja Bersama yang selanjutnya disingkat PKB adalah perjanjian yang merupakan hasil perundingan antara serikat pekerja/serikat buruh atau beberapa serikat pekerja/serikat buruh yang tercatat pada instansi yang bertanggung jawab di bidang ketenagakerjaan dengan pengusaha, atau beberapa pengusaha atau perkumpulan pengusaha yang memuat syarat-syarat kerja, hak dan kewajiban kedua belah pihak.

29. Penyerahan Sebagian Pelaksanaan Pekerjaan Kepada Pihak Lain yang selanjutnya disebut Alih Daya adalah penyerahan sebagian pelaksanaan pekerjaan kepada Perusahaan Penyedia Jasa melalui perjanjian pemborongan pekerjaan dan/atau melalui perjanjian penyediaan jasa tenaga kerja.

30. Pemutusan Hubungan Kerja adalah pengakhiran hubungan kerja karena karena suatu hal tertentu yang mengakibatkan berakhirnya hak dan kewajiban antara Pekerja/Buruh dan pengusaha.

31. Tenaga Kerja Informal adalah tenaga kerja yang melakukan 
pekerjaan pada rumah tangga dengan upah tertentu.

32. Penyandang Cacat yang selanjutnya disebut Penyandang Disabilitas adalah setiap orang yang mempunyai kelainan fisik dan atau mental yang dapat mengganggu atau merupakan rintangan dan hambatan baginya untuk melakukan secara selayaknya yang terdiri dari penyandang cacat fisik, penyandang cacat mental, dan penyandang cacat fisik dan mental.

33. Upah adalah hak Pekerja/Buruh yang diterima dan dinyatakan dalam bentuk uang sebagai imbalan dari pengusaha atau pemberi kerja kepada Pekerja/Buruh yang ditetapkan dan dibayarkan menurut suatu PK, kesepakatan, atau peraturan perundang-undangan, termasuk tunjangan bagi Pekerja/Buruh dan keluarganya atas suatu pekerja dan/atau jasa yang telah atau akan dilakukan.

\section{Upah Minimum}

Provinsi yang selanjutnya disingkat UMP adalah upah minimum yang berlaku di Aceh.

\section{Kesejahteraan}

Pekerja/Buruh adalah suatu pemenuhan kebutuhan dan/atau keperluan yang bersifat jasmaniah dan rohaniah, baik di dalam maupun di luar hubungan kerja, yang secara langsung atau tidak langsung dapat mempertinggi produktivitas kerja dalam lingkungan kerja yang aman dan sehat.

\section{Pengawasan}

Ketenagakerjaan adalah kegiatan mengawasi dan menegakkan pelaksanaan peraturan perundangundangan di bidang ketenagakerjaan.

37. Menteri adalah menteri yang bertanggung jawab di bidang ketenagakerjaan

38. Instansi Non

Pemerintah adalah instansi yang didirikan oleh masayakat.

39. Upah adalah hak Pekerja/Buruh yang diterima dan dinyatakan dalam bentuk uang sebagai imbalan dari pengusaha atau pembari kerja kepada Pekerja/Buruh yang ditetapkan dan dibayarkan menurut suatu PK, kesepakatan, atau peraturan perundang-undangan, termasuk tunjangan bagi Pekerja/Buruh dan keluarganya atas suatu pekerjaan dan/atau jasa yang telah atau akan dilakukan.

40. Skala Upah adalah kisaran nilai nominal upah untuk setiap kelompok jabatan.

\section{Perselisihan Hubungan} Industrial adalah perbedaan pendapat yang mengakibatkan pertentangan antara pengusaha atau gabungan 
pengusaha dengan Pekerja/Buruh atau serikat pekerja/serikat buruh karena adanya perselisihan mengenai hak, perselisihan kepentingan, perselisihan pemutusan hubungan kerja dan perselisihan antar serikat pekerja/serikat buruh dalam satu perusahaan.

\section{Mediasi Hubungan}

Industrial yang selanjutnya disebut Mediasi adalah penyelesaian perselisihan hak, perselisihan kepentingan, perselisihan pemutusan hubungan kerja, dan perselisihan antar serikat pekerja/serikat buruh hanya dalam satu perusahaan melalui musyawarah yang ditengahi oleh seorang atau lebih mediator yang netral.

\section{Mediator Hubungan}

Industrial yang selanjutnya disebut Mediator adalah pegawai instansi pemerintah yang bertanggung jawab dibidang ketenagakerjaan yang memenuhi syarat-syarat sebagai mediator yang ditetapkan oleh Menteri untuk bertugas melakukan mediasi dan mempunyai kewajiban memberikan anjuran tertulis kepada para pihak yang berselisih untuk menyelesaikan perselisihan hak, perselisihan kepentingan, perselisihan pemutusan hubungan kerja, dan perselisihan antar serikat pekerja/ serikat buruh hanya dalam satu perusahaan.
44. Pembinaan Hubungan Industrial adalah serangkaian usaha yang dimaksudkan untuk mewujudkan kemampuan dan kesadaran para pihak yang terlibat dalam proses produksi barang dan jasa yaitu pekerja dan organisasinya, pengusaha dan organisasinya serta pemerintah terhadap norma-norma yang berlaku sehingga menumbuhkan keserasian dan iklim usaha yang sehat serta kesejahteraan pekerja.

\section{Pengembangan}

Hubungan Industrial adalah serangkaian usaha menciptakan, menyempurnakan, mengembangkan sistem, metode, teknis hubungan industrial agar dapat memenuhi tuntutan perkembangan dan perubahan situasi serta kondisi ketenagakerjaan baik pada lingkup sektoral, regional maupun internasional.

46. Perselisihan Hak adalah perselisihan yang timbul karena tidak dipenuhinya hak, akibat adanya perbedaan pelaksanaan atau penafsiran terhadap ketentuan peraturan perundang-undangan, $\mathrm{PK}, \quad$ peraturan perusahaan, atau PKB.

\section{Perselisihan}

Kepentingan adalah perselisihan yang timbul dalam hubungan kerja karena tidak adanya kesesuaian pendapat mengenai pembuatan, dan/atau 
perubahan syarat-syarat kerja yang ditetapkan dalam PK, atau peraturan perusahaan, atau PKB.

48. Perselisihan Pemutusan Hubungan Kerja adalah perselisihan yang timbul karena tidak adanya kesesuaian pendapat mengenai pengakhiran hubungan kerja yang dilakukan oleh salah satu pihak.

49. Perselisihan Antar Serikat Pekerja/Serikat Buruh adalah perselisihan antara serikat pekerja/serikat buruh dengan serikat pekerja/serikat buruh lain hanya dalam satu perusahaan, karena tidak adanya persesuaian paham mengenai keanggotaan, pelaksanaan hak, dan kewajiban keserikat pekerjaan.

50. Tenaga Kerja Yang Melakukan Pekerjaan di luar Hubungan Kerja adalah setiap orang yang bekerja atau berusaha atas risiko sendiri.

51. Tanggung Jawab Sosial dan Lingkungan yang selanjutnya disebut Tanggung Jawab Sosial Perusahaan (Corporate Social Responsibility) adalah komitmen perusahaan untuk berperanserta dalam pembangunan ekonomi berkelanjutan guna meningkatkan kualitas kehidupan dan lingkungan yang bermanfaat, baik bagi perusahaan sendiri, komunitas setempat, maupun masyarakat pada umumnya.

52. Pegawai Pengawas Ketenagakerjaan yang selanjutnya disebut pengawas ketenagakerjaan adalah pegawai negeri sipil yang diangkat dan ditugaskan dalam jabatan fungsional pengawas ketenagakerjaan sesuai dengan ketentuan perundangundangan.

Selanjutnya Pasal

menyebutkan Penyelenggaraan

Ketenagakerjaan bertujuan:

a. menetapkan kebijakan dan menyusun perencanaan tenaga kerja;

b. menciptakan sistem latihan kerja yang berbasis masyarakat, kompeten, dan berkesinambungan;

c. menyediakan tenaga kerja sesuai kebutuhan pembangunan Aceh secara kualitatif dan kuantitatif;

d. menciptakan iklim investasi/usaha yang kondusif demi tercapainya perluasan kesempatan kerja melalui penyusunan kebijakan produktifitas bagi tenaga kerja dan perusahaan; 
e. mewujudkan hubungan industrial yang harmonis, dinamis, berkeadilan dan kearifan lokal;

f. membina, mengembangkan dan menyelesaikan perselisihan hubungan industrial/PHK secara bijak tanpa merugikan pihakpihak dengan mempertimbangkan kelangsungan usaha;

g. memberikan perlindungan dan meningkatkan kesejahteraan kepada tenaga kerja dan keluarganya;

h. mewujudkan kepedulian sosial terhadap lingkungan di sekitar perusahaan; dan

i. meningkatkan hubungan kerjasama dengan lembaga atau badan di luar negeri.

Berdasarkan peraturan Qanun tersebut diatas maka Peran Pemerintahan Aceh dalam memberikana pendidikan dan pelatihan Tenaga Kerja suatu kewajiban yang harus dilaksanakan oleh Pemerintahan Aceh yang sesuia kebutuhan lapangan kerja sangat berperan karena Qanun Aceh tentang Ketenagakerjaan ini, merupakan amanah Undang-Undang Nomor 11 Tahun 2006 tentang Pemerintahan Aceh yang harus dilakasanakan dengan tujuan untuk meningkatkan kesejahteraan Pekerja di Aceh dan Nasioanl secara umum.

\section{PENUTUP}

Berdasarkan ketentuan Pasal 175 Undang-Undang Nomor 11 Tahun 2006 tentang Pemerintahan Aceh, setiap tenaga kerja mempunyai hak yang sama untuk mendapat pekerjaan yang layak di Aceh. Dalam hal ini Pemerintah Aceh dan Pemerintah Kabupaten/Kota memberikan kesempatan dan pelindungan kerja bagi tenaga kerja di Aceh dan dapat bekerja sama dengan pemerintah provinsi dan kabupaten/kota asal tenaga kerja yang bersangkutan. Selanjutnya, semua tenaga kerja di Aceh harus terdaftar pada instansi yang bertanggung jawab di bidang ketenagakerjaan masing-masing Kabupaten/Kota. Karena hak dan kewajiban Pemeritahan Daerah telah diberikan Otonomi Daerah yang mengatur dan memberikan wewenang dan kewajiban yang lebih menekan pada daerah otonom untuk mengatur dan mengurus sendiri urusan pemerintahan dan kepentingan masyarakat setempat sesuai dengan peraturan perundangundangan dengan tujuan meningkatkan kesejahteraan masyarakat, pelayanan umum dan daya sain daerah. Untuk 
mendukung meningkatkan ketrampilan tenaga kerja yang sesuai dengan kebutuhan tempat kerja maka Pemerintahan Aceh sangat berperan dalam memberikan pendidikan dan pelatihan untuk tenaga kerja yang siap pakai di dalam lapangan kerja dengan mengeluarkan Peraturan Gubernur Aceh Nomor 112 Tahun 2016 tentang Kedudukan, Susunan Organisasi, Tugas, Fungsi dan Tata Kerja Dinas Tenaga kerja dan mobilitas Penduduk Aceh.

\section{DAFTAR PUSTAKA}

Jhonny Ibrahim, (2006). Teori \& Metodologi Penelitian Hukum Normatif, Malang: Bayumedia Publishing.

Imam Kabul, (2005). Paradigma Pebangunan Hukum Di Indonesia. Guna widya: Surabaya

Kontjaraningrat, (1997). Metode-Metode Penelitian Masyarakat, Jakarta : PT. Gramedia.

Moenir, (2000), Ilmu Administrasi Publik, Jakarta, Rineka Cipta,

Romli, Atmasasmita. (1991). teori dan kapita selekta kriminologi dalam suatu bunga rampai. Bandung: Eresco

Soerjono Soekanto \& Sri Mamudji, (2007) "Penelitian Hukum Normati Suatu Tingjauan Singkat", Jakarta; PT. Raja Grafindo Persada.

Suhaidi, (2007), Bahan Kuliah Teori Hukum, Program Studi Ilmu Hukum Sekolah Pascasarjana USU.
Sunaryati Hartono, (1994), "Penelitian Hukum di Idonesia Pada Akhir Abad ke20", Bandung: Alumni.

Modeong, Supardan, (2003), Teknik Perundang-undangan di Indonesia, Jakarta: Perca,

Munir Fuadi, Dinamika Teori Hukum,(2007), Bogor: Ghalia Indonesia.

Bismar Nasution dan Mahmul Seregar, (2006), Bahan Kuliah Teori Hukum, Program Studi Ilmu Hukum Sekolah Pascasarjana USU. 